\title{
Mythologizing the Story of Creation in Indaba, My Children Lamees Younis (PhD)
}

Department of English Language and Literature Faculty of Women, Ain Shams University lamees.younis@women.asu.edu.eg DOI: $10.21608 /$ MISJ.2020.44130.1006

\begin{abstract}
This paper aims at studying the story of the creation of the universe in Book One of the Bantu Text Indaba, My Children (1964) in an attempt to contextualize it within parallel creation myths from other traditions and cultures. The paper claims that the text under study is a creation myth, which is viewed as a sacred text with a cosmogonic function: to inform about the creation of the universe. To achieve this end, the researcher compares the common motifs recurrent in two of the most famous creation myths: the Book of Genesis of the Hebrew Bible and the Babylonian creation myth known as the Enûma Eliš on one hand, and the ones found in Indaba, My Children on the other. These motifs are the sexual act as a means of creation, the human form of the first creative being, bringing order after a state of chaos, and creation out of the feeling of loneliness. Through comparing those recurrent motifs in the above-mentioned texts, the researcher asserts that creation myths, even if they are geographically apart, share certain motifs and features that distinguish all of them.
\end{abstract}

Keywords: Bantu, creation myth, Genesis, Enûma Eliš, Indaba.

\section{Introduction}

This paper aims at studying the story of creation offered in Book One of the Bantu text: Indaba, My Children (1964) by Credo Mutwa (1921-2020) in an attempt to contextualize it within parallel creation myths from other traditions and cultures. To achieve this end, the researcher compares the common motifs recurrent in two of the most famous creation myths: the Book of Genesis of the 
Hebrew Bible and the Babylonian creation myth known as the Enûma Eliš on one hand and the ones found in Indaba, My Children on the other. ${ }^{\text {i }}$ These motifs are: the sexual act as a means of creation, the human form of the first creative being, bringing order after a state of chaos, and creation out of the feeling of loneliness. Through comparing those recurrent motifs in the above-mentioned texts, the researcher asserts that creation myths, even if they are geographically apart, share certain motifs and features that distinguish them all. ${ }^{\text {ii }}$

The researcher has selected the Enûma Eliš and the Book of Genesis of the Hebrew Bible for their significance to the study of creation myths all over the world. The boundless popularity of the Enûma Eliš lies in its "great significance for the study of the theogonic and cosmogonic views of the Mesopotamians, and thus for a comparative study of ancient Near Eastern religion in general." Moreover, the Enûma Eliš shows "quite a number of analogies to the first two chapters of the Book of Genesis" (Heidel 1). The biblical literature has its historical and cultural significance. iii $^{\text {It }}$ "brought its view of God, the universe, and mankind into all the leading Western languages," hence, shaping the intellect of the Western man. The translations of the Bible "led to the study and literary development of many languages." The Biblical literature has also affected the modern age "in the arts" and literature "of Western people" especially "in their ... creative fiction" ("Biblical literature"). ${ }^{\text {iv }}$

Among the points of resemblance that the Enûma Eliš and the Hebrew Bible share are the reference to "a watery chaos" (Heidel 97) that is also found in the Egyptian and the Phoenician cosmologies (qtd. in Heidel 97) as well as the idea of a primeval darkness (Heidel 101). Of the other points of resemblance is the formation of heaven and earth through "division or separation" (115) as well as the creation of the "[1] uminaries" (116). The creation of man, which comes as "the final act of creation" in both the Hebrew Bible and the Enûma Eliš, is another point of similarity between the two creation myths (119). The power of the word of God in the Genesis who said "Let there be light" (New Revised Standard Version Gen. 1.3) and Marduk in the Enûma Eliš who "restor[ed] a garment at the word of his mouth" (Heidel 126) is another point of resemblance. " The point of "[d]ivine [r]est" (127) is the last point of resemblance between the Book of Genesis and the Enûma Eliš to be mentioned in the paper. 


\section{Defining Myth}

In Cassell's Encyclopaedia of Literature, myth is defined as a "tale," and "in the original sense of the Greek word muthos any tale would be a myth, because it would be an oral communication." "vi Then, 'muthos' developed to be a particular type of tale: "a story for those who tell it and for those who receive it" and that "has a kind of cosmic purpose." It is a story that "professes to relate some happening in which supernatural beings are concerned and probably in so doing to offer an explanation of some natural phenomenon" (372). However, this definition might not be sufficient in an attempt to differentiate between myth and other narrative forms.

In his article "The Forms of Folklore: Prose Narrative" that mostly focuses on creation and etiological myths, William Bascom (1912-1981) uses the liturgical function of myth in defining it. He indicates that one can resort to belief, time, place, attitude, and principal characters to differentiate between the three types of "folk narratives" under examination: myths, legends, and folktales (8-9). For Bascom, in a given society people are told that myths are "prose narratives which ... are considered to be truthful accounts of what happened in the remote past." Such myths are "accepted on faith" and "taught to be believed." Defining myth based on Bascom's criteria of belief and time makes myth a sacred narrative that tells the tale of "the remote past." Hence, myth is the incarnation of "dogma" that is "associated with theology and ritual" (9).

The question, then, is why are theologians and scientists interested in myth, however, with different perspectives? As Max Weber claims, every theology assumes that the world has a meaning (28), and since myth is the sacred text with liturgical functions of the primitive man and since it manifests his attempt to explain the cosmos around him in a 'semi-scientific' manner, there has always been an interest in studying it. ${ }^{\text {vii }}$ Moreover, myth is a form of art that can enable us, according to Jürgen Habermas, to understand "the world" and "the self" (9).

One of the old attempts to study myth started in the eighteenth century by the philosophes. ${ }^{\text {viii }}$ Their most bewildering question was "the genesis of religion. How, when, and why did it start?" Philosophes were students of religion as a "phenomenon" and "as a creation of the human spirit." Their attempt to answer this question led them to examine religion through "a close analysis of pagan mythology" (Ackerman 2). One of the most important contributions of the DOI: $10.21608 / \mathrm{MISJ} .2020 .44130 .1006$

Mișriqiyā Vol. 1 Issue 1 (2021) 
philosophes is reducing the multiplicity of deities to "a relative handful of deities from some leading nation-Egypt, Babylon, Phoenicia-which then argued was the center from which all other institutions of paganism derived" (4). ${ }^{\mathrm{ix}}$

One of the most important contributors to the study of myth and the notion of its parallel development is Bernard Fontenelle (1657-1757). It is the parallel development, according to Fontenelle, that explains the similarities between different myths of divergent geographical areas and distant nations. According to him, myth is not the manifestation of "some sage's wisdom," nor "some enormous imposition by wily priests in antiquity." It is, rather, "the direct and inevitable consequence of man's psychological nature." Hence, myth "provid[e]s a remarkable insight into the thought process of primitive humanity." Beside attesting the common belief that the ancients created their gods "in their own image," Fontenelle declares that this act was the "projection of man's psychic nature" (5) and that it was done "continuously and progressively" (5-6).

Among those theorists that share a close perspective with Fontenelle is the anthropologist Edward Burnett Tylor (1832-1917) whose starting point was "the premise that a fundamental unity exists among people, and that the similarities and continuities in human culture far outweigh the differences and discontinuities" (36). Consequently, stating that change came in an organized and systematic manner and that the human institutions "once simple and confused, had become complex and highly coordinated over the passage of time" (36-37). This reflects a 'rational' and 'scientific' attitude that governs Taylor's thinking pattern.

\section{Indaba, My Children (1964)}

As its cover page indicates, the South African text Indaba, My children, 'told' by Credo Mutwa (1921-2020), is a book of "African Tribal History, Legends, Customs and Religious Beliefs" (Mutwa). ${ }^{\mathrm{x}}$ Mutwa offers the readers the history of "the Bantu Africa" (xv). It is the oral heritage of the tribe reserved by the "Guardians of the Umlando" or the tribal history keepers who orally preserve their heritage (xvi). ${ }^{\mathrm{xi}}$ The story of creation of the Bantu people that Mutwa recites comes in 'Book One' of Indaba, My Children. This book consists of ten episodes and a 'Postscript.' Nine of these episodes are in verse while the Postscript and the last episode entitled "The Span of the Dragon" are in prose. 
This research paper studies eight episodes of 'Book One' in addition to the 'Postscript.' The episodes are "The Self-Created" (5), "Behold the First is Born!" (18), "The Race that Died" (21), "Thy Doom, Oh Amarire!" (30) "The Last Sin of Za-Ha-Rrellel" (34), "Behold the Survivors!" (43), "Between Gorogo and Odu" (52), and "The Bud Slowly Opens" (61).

The analysis of the first book of Indaba, My Children reveals the recurrence of four motifs that distinguish many creation myths all over the world. These motifs are the sexual act as a means of creation, the human form of the first creative being, bringing order after a state of chaos, and creation out of the feeling of loneliness.

In his book 'asâțīr 'al-'awalīn (Myths of the Ancestors) firās as-sawāh mentions that the Sumerian myths that are "the oldest recorded myths in the ancient East," state that the world was created from "the first water hyle". xii This first water hyle gave birth to the sky and the earth which through their mating, gave birth to the air (173). We can identify here the recurrence of the motif of the sexual act in the process of creation even if it does not come in its very initial phase. $^{\text {xiii }}$

This motif of the role the sexual act as a source of creation appears in the first episode: "The Bud Slowly Opens." The episode starts with introducing "Nothingness" that existed and which was "neither hot nor cold." This nothingness "float[ed] / ... / Upon the invisible waters of Time." Then the River Time "desired" Nothingness "Like a flesh-and-blood male beast / Desires his female partner." As a result of this peculiar "mating," (Mutwa 5) "Fire was born" (6). Hence, the role of sexual intercourse is strongly asserted in the process of creation.

Once More, the motif of creation through the sexual act reappears in the second episode when Ma, the "very first Goddess of human shape" (8) mates with the Tree of Life and gives birth "after a thousand years" (18). The mother goddess gives birth to "[a] countless number of human beings" and the "[g]reen buds burst from [the Tree of Life's] writhing limbs / And clouds of seeds emerged and fell upon the rocky plains." As the goddess Ma continues giving birth to human beings, buds continue to emerge out of the limbs of the Tree of Life and "mountains," beside birds like "[o]striches," "hawks," "flamingoes," "beasts," 
and the holy "Kaa-U-La" birds. In short, the barren and "dead" earth starts "to live" (19). ${ }^{\text {xiv }}$ Mutwa adds that from "the roots" of the Tree of Life, appeared the "reptiles of all kinds and shapes" as well as "all sorts of insects." Mutwa affirms that "[t]he Song of Life had begun on earth-." Nevertheless, this song "will no doubt set one day fore'er!" (20).

The first two episodes of the Bantu text reflect the analogy between it and the Babylonian creation myth. In the first episode, the battle between Fire and its mother, Nothingness, manifests this resemblance. Mutwa depicts Fire that grew aware of itself and there is "an awakening to consciousness" (Franz ch. 2) that is represented in her saying "'I exist — I am what I am!'." It is trying to "flee from where there is no escape." This motivates her, Fire, to enlarge its size by being "fed upon itself." Then Mutwa offers us the battle between Fire and its mother, Nothingness, in which the latter "cast[s] a spell of cold upon the spark;" that was "Cold - a deadly foe of heat" that induced Fire to get hotter (Mutwa 6). This battle between Fire and Nothingness is the Bantu version of the Babylonian battle between Marduk, the "patron of Babylon" and its "Bel" or "Lord" (Dalley 325), and his grandmother Tiamat the "[m]other of the first generation of gods" that "[e]pitomizes chaos" (329) in tablet IV of the Enûma Eliš. ${ }^{\mathrm{xv}}$

An additional similarity between Indaba, My Children, and the Enûma Eliš is shown in the discussion between the Tree of Life and Ma that resembles the one between Apsu the "father of the primitive gods" (318) and Tiamat. After ZaHa-Rrellel, the symbol of evil in the Bantu text, causes the First People created to be sterile, the Tree of Life thinks that his offspring should be abolished as they are "depriving" life of "its purpose!" that is to "beget their kind" (Mutwa 32). ${ }^{\mathrm{xvi}}$ $\mathrm{Ma}$, as the mother who bore these First People, prefers to "send them a warning first" as she cannot imagine destroying her "first effort." For her, it was "that evil tyrant" Za-Ha-Rrellel "[w] ho has gone and led them astray" (32). This dialogue paves the road for Za-Ha-Rrellel's punishment and his end after he decides to capture Ma (35).

Both Apsu, "the first one," and the Tree of Life take the same stance against their offspring. In tablet I of the Babylonian creation myth, Apsu could not "quell" his offspring's noise (Dalley 323). He suggests that, with Tiamat the "[m]other of the first generation of gods" (329), he "shall abolish their ways and disperse them!" so silence and "peace" may "prevail" and he can sleep. Tiamat 
answers him vigorously and shouts at "her lover" Apsu, saying: "[h]ow could we allow what we ourselves created to perish?" even if "their ways are so grievous." As their mother, she thinks that they "should bear it patiently" (234). While Apsu resembles the Tree of Life who wants to abolish his offspring just because they made a mistake, Ma resembles Tiamat who is, here, more merciful and wants to give them another chance.

The motif of "the human form of the first creative being, an anthropos (sic.) figure" (Franz, ch. 2) is manifested not only in the creation of the goddess Ma but in the creation of Adam as well, nonetheless, with a slight difference. From "the still warm ashes - wounds in Flame's existence, / Inflicted in Battle by the Spirit of Cold, / There arose the Great Mother Ma," (Mutwa 7) who is the main Goddess "of human shape" (8). This goes with Fontenelle's view that man created his gods in his own image. In the Hebrew Bible, although Adam is not a typical creative being, he is the first Anthropos figure. Adam is a secondary creative figure as, through performing the sexual act with Eve, he 'creates' human beings. It can be said that according to this motif, and due to being a 'creator,' Adam is the first 'Anthropos figure.' We see God, the creator, in Book One of the Genesis creating Adam "in [His own] image" and "after [His] likeness" (Gen. 1.26). ${ }^{\text {xii }}$

Creating the goddess Ma, who is "[a]1l-knowing Omniscient" and "[m]ostmerciful" and who created herself "by the Great Spirit's wish" (Mutwa 8) manifests the motif of bringing order after a state of chaos. The Great Spirit was "displeased with the wasteful and senseless War / Between the Flame and the Cold." Thus, he came "from far beyond / The Ten Gates of Eternity" to establish the universal order (8). The motif of bringing order after a state of chaos is, therefore, inherent both in the Bantu text and the Babylonian creation myth. This chaos prevailed before the emergence of "the world parents" ("Creation myth"). Chaos is what prevails before the creation of Ma and the Tree of Life: the parents of the First People, and before the creation of Apsu and Tiamat: the parents of the primeval gods. Moreover, at the end of the fifth tablet and in the sixth tablet we see Marduk, after killing Tiamat, bringing order to Heavens (Dalley 254), "designat[ing] the year" (255), and creating the skies (256).

The creation of the First People is a proof of the analogy between the Bantu text and the Hebrew Bible. In "The Race that Died" the sons and daughters of the Tree of Life and Ma called the "First People" are introduced. They were the 
earliest men to walk on earth and they were all identical. Their "colour was red like Africa's plains" (Mutwa 21). Nonetheless, the later "splitting of all Humanity into races; / ... / Resulted from one great accident which occurred / Through the sinfulness of these First Men" (21). This recalls the incident of bewildering the language of the people of the earth after they used to speak one language.

Chapters ten and eleven of the Genesis offer a similar idea of the resemblance among people. In those chapters, it is mentioned that "the whole world had one language and a common speech" (Gen. 11.1). The "the descendants of Noah's sons, Shem, Ham, and Japheth" and their sons who "were born to them after the flood" (Gen. 10.1) feared the "possibility of a periodical deluge" (Barnes, "Genesis 11"); that is why they decided to build "a city, and a tower with its top in the heavens" (Gen. 11.4). This reflects the hidden inclination for "empire" and self-glorification "to the design of the leaders" that is a new shape of the egocentric spirit that "animated the antediluvian men" (Barnes, "Genesis 11"). God, upon seeing them on the verge of sinning, decided to "confuse their language there, so that they will not understand one another's speech" (Gen. 11.7). Thus, the difference among both the sons of Noah and the sons of Africa came as a punishment for sin.

Even this deluge has its echoes in Indaba, My Children that we can find in "Thy Doom, Oh Amarire!" As Ma and the Tree of Life agree upon warning their First Generation that sinned and strayed away from the purpose of life (Mutwa 32), the Tree of Life "ordered clouds / To gather and cover the earth, / Obstruct the sun, and ravage all" and "the empire's land were covered / In waters many feet deep" and half of the First People drowned (33).

The motif of creation out of the feeling of loneliness also emphasizes the resemblance between the Bantu text and the Book of Genesis. In the seventh chapter of Creation Myths, Franz discusses the "subjective moods of creation" or the mental and emotional states that led the gods to create the world. One of these subjective moods is "loneliness" (ch. 7). In Indaba, My Children, we see Ma lament being lonely (Mutwa 9). Here it is not the Great Spirit feeling lonely that led him to create Ma or any other creations. It is Ma's loneliness and asking for a mate that made the Great Spirit grant her one. The same motif of loneliness recurs in the Book of Genesis in which Adam is identified by God to be alone. God sees that it is "not good that the man should be alone" and He "make[s] him a helper 
as his partner" (Gen. 2.18). Adam gets his mate, Eve, just as Ma gets the Tree of Life.

Examining Book one of the Bantu text, Indaba, My Children reveals it has a cosmogonic function: it tells how the universe emerged and it tells the tale of the remote past. As such, the text is believed to be viewed as a sacred text by the Zulu people, as it includes motifs like the sexual act as a source of creation, the motif of the human form of the first creative being, an Anthropos figure, the motif of bringing order after chaos, and the motif of loneliness recurrent in it, the Book of Genesis of the Hebrew Bible, and the Babylonian creation myth: the Enûma Eliš as well, I come to conclude that Book One of Indaba, My Children is the Bantu creation myth. The resemblance found between the text under study, the Book of Genesis, and the Enûma Eliš makes of Book One of Indaba, My Children a Bantu Genesis. This asserts that creation myths, even if they are geographically apart, share certain motifs and features that distinguish them all.

\section{Notes}

1 The Hebrew Bible is also known as the "Hebrew Scripture," "the Old Testament," or "Tanakh." It functions as the sacred books of the Jewish people." This Hebrew Bible constructs "a large portion of the Christian Bible" ("Hebrew Bible"). It compiles the Torah that is "the first five books called the Law (or the Pentateuch, in Christianity)." These five books are attributed to Moses. Jews, along with different Christian denominations like Roman Catholics, Eastern Orthodox, and Protestants "all agree on their

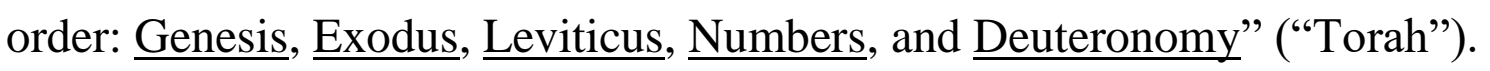

2 Being of a Muslim background, the researcher alludes, when relevant, to the Islamic heritage manifested in the Qur'ān and its "exegesis" known in Arabic as tafsīr or "the Qur'ānic commentary" ("Tafsīr")

3 The Biblical literature is the "four bodies of written works" or the "Old Testament" with its "Apocrypha" as well as the "New Testament" and its 
"Apocrypha" ("Biblical literature"). The word Apocrypha in the biblical literature refers to "works outside an accepted canon of scripture" ("Apocrypha").

${ }^{4}$ One of the earliest and most important books in the field of the Babylonian and Assyrian myths is The Chaldean Account of Genesis by the British Archaeologist George Smith (1840-1876). He denotes that the Sir Henry Rawlinson (18101895), British orientalist, was the one who proposed "the great probability that" the story of the creation in the Genesis "had a Babylonian origin" (3). Smith himself mentions that he "noticed referencés to the Creation in a tablet numbered K 63" in the British Museum collection (3-4). This made Smith search other tablets that he classified before as "Mythological" to find some of the legends related to the creation of the world. This search led him to a tablet telling the story of what he believed to be "the Chaldean account of the Deluge" (4).

The word Chaldea refers to the area in "southern Babylonia" that was raided by Shalmaneser III of Assyria (reigned 858-824 bc) in "850." However, as the Assyrian power declined, "Nabopolassar," "the native governor," "was able, in 625 , to become the king of Babylon" and to "inaugurate a Chaldean dynasty that lasted until the Persian invasion of 539 bc." It is his prestigious successors: "Nebuchadrezzar II (reigned 605-562) and Nabonidus (reigned 556-539)" who caused "Chaldean" to become "synonymous with "Babylonian." The word Chaldean was also used by a few "ancient authors" to refer to "the priests" who were "educated in" and aquatinted with "the classical Babylonian literature" ("Chaldea").

The origin of most, "if not all" of the Babylonian and Assyrian legends are "of Chaldean or Babylonian origin." Smith elaborates that the Assyrians either "copied Babylonian originals or simply put into a new form the story they had borrowed from their southern neighbours." These legends "mount back to a date earlier than the second millennium before the Christian era" (Smith 10). In the chapter entitled "Babylonian Legend of the Creation," Smith mentions the correspondence between the Babylonian creation myth and the first chapter of the Book of Genesis of the Hebrew Bible (59). Smith elaborates that the "early Babylonian legends, of which copies were made for the Assyrian Library at Koyunjik, were but selected few" as the Assyrians "took little interest in that part of Babylonian literature which had no connection with their own history or 
beliefs." Among the "traditions" that the Assyrians borrowed from "their older and more civilized neighbours were ... the earlier chapters of Genesis" (7).

${ }^{5}$ The New Standard Revised Version (NSRV) of the Bible is use in this paper since scholars of the Protestant, Eastern Orthodox, and Roman Catholic denominations as well as Jewish scholars, who translated the Old Testament, participated in producing it. The NSRV aims at preserving the merits of the King James Version (KJV) ("Biblical literature"), that is a disfavored edition "among many mainstream Protestant churches" ("King James Version (KJV)") "and the Revised Standard Version (RSV) of the Bible "while acknowledging linguistic and archaeological discoveries" in the second half of the twentieth century that complemented to the "knowledge of the social, cultural, and theological context of the biblical world" ("Biblical literature").

${ }^{6}$ In A Philosophy of Political Myth, Chiara Bottici states that mythos is a "Greek word which originally meant 'word, speech'." She adds that "according to certain etymologists, it derives from a popular expression constituted by the onomatopoeic sound $m u-\ldots$ and the common suffix -thos" (20). By the time of the Homeric poems, around the eighth century BC, "mythos began to express the additional meaning of a 'tale"' (21).

${ }^{7}$ In mughāmarat-l-áql-l-' 'ula, firās as-sawāh mentions that the creation of the universe and man was one of the first issues that concerned man. He declares that one can hardly find a nation without a myth or a set of myths that deal with creation (as-sawāḥ, mughāmarat 27). In surah al-'ān 'ām, the Qur'ān offers Abraham's ('ibrāhīm in Arabic) "stages of ... spiritual enlightenment." The reader sees how old the quest for a god is. Abraham refuses to worship his ancestral idols and thinks about worshiping "a star shining in the darkness of the night," (Ali 314) then "the moon," and finally, "the sun." Though, when he finds that the three "heavenly bodies" set, he decides to worship Allah "Who created [t]he heavens and the earth" (315).

${ }^{8}$ Philosophes were "any of the literary men, scientists, and thinkers" of the eighteenth century France "who were united, in spite of divergent personal views, in their conviction of the supremacy and efficacy of human reason" ("Philosophe").

${ }^{9}$ For more information, see Ackerman's The Myth Ritual School 4-5. 
${ }^{10}$ Indaba is a "Zulu" word that means "conference" ("indaba") or "meeting" (Mavhunga and Dressler 45)

${ }^{11}$ Credo Mutwa was born in South Africa for a "Catholic catechist" father and a 'pagan' mother who was the daughter of "a custodian of the relics" of the Zulu people, who are "a branch of the southern Bantu" ("Zulu"), and a "Guardian" of the "Tribe's History" (Mutwa Xx). After living as a Christian for thirty years away from the Zululand, Mutwa returns to his maternal family, embraces the indigenous religion, and is prepared to be a "Custodian" of the "sacred Tribal Relics" after the death of his grandfather (xxi).

Indab, My Children, 'told' by Mutwa, is the oral heritage of the tribe reserved by the tribal history keepers who orally preserved their heritage (xvi). After the coming of Christianity and with its becoming the main religion in South Africa, the indigenous African religion ebbed. Living the turmoil that South Africa witnessed as a result of the apartheid, Mutwa thought that it is the disclosure of this heritage that would help "the white rulers of Africa" to have "better knowledge and a better understanding of the way a Blackman's mind works" (xii). Mutwa, who is a custodian of this heritage and religious beliefs, decides to record this oral history and bear "the stigma of traitor" for the benefit of Africa.

However, in his article "Credo Mutwa, Zulu Shaman: The Invention and Appropriation of Indigenous Authenticity in African Folk Religion," David Chidester mentions that indaba is a term that refers to a "Zulu tribal council" in which various views are presented (Chedister 69) to "have their authenticity or acceptability evaluated" (qtd. in Chedister 69). He adds that the publication of Indaba, My Children did not help in asserting its authenticity and being a part of the Zulu heritage. Nevertheless, James Randolph Vigne (1928-2016), the antiapartheid activist ("James Randolph Vigne"), sees that by attributing Indaba, My Children to the Zulu tradition, Mutwa wants to show the uniqueness of the African culture and that it is "unassimilable with any other" culture especially with that of the Europeans inhabiting South Africa (qtd. in Chedister 69)

${ }^{12}$ All translations are mine unless otherwise stated.

Hyle comes from the "Greek" word "hylē" which means "mater" specifically "in its primordial" and "unrecognized state" ("Hyle"). 
${ }^{13}$ Franz mentions that "in many primitive societies," we find the myth of the creation of the world through "the sexual act." It offers "how out of nothing, ... something is created in a completely natural way." She adds that the creation myths that "attribute the origin of the word to the sexual union of father and mother ... skip over the beginning and go to the next step." As she goes on, it is "just an easy way of explaining one miracle by another" (ch. 2).

${ }^{14}$ The idea of a tree of life is not confined to the Bantu tradition. In Norse mythology, "Yggdrasill" is the "world tree." It is an enormous "ash" tree "supporting the universe." Despite being "badly shaken" after "Ragnarök" or the "Doomsday," this ash tree was "the source of new life" ("Yggdrasill").

In the Christian myth, the idea of the tree of life is also found in the Book of Genesis. In his commentary on book two of the Genesis, Andrew Gray mentions that in the Paradise of Eden, there were "beautiful trees" in addition to "the tree of life" and the tree of "the knowledge of good and evil" which were "sacramental trees." Gray elaborates that the Tree of Life "is Christ" (Gray).

${ }^{15}$ For more information, see the Enûma Eliš in Dalley's Myths from Mesopotamia 249-55.

${ }^{16}$ Notice the similarity between the Bantu concept of the importance of mating and having children and the Islamic concept of Allah settling man in the earth that came in Qur'an, Surah Hud: "It is He Who hath produced you [f]rom the earth and settled you [t]herein" ('Alī 527).

${ }^{16}$ As it is mentioned in The Study Quran, in surah al-baqarah, the reader is offered the story of the fall of Adam and Eve, however, with "fewer details." "[M]uch of the details" about the story of the fall mentioned by "[s]ome commentators ... find their origin in Jewish and Christian, and perhaps even Arab, oral traditions." The name Eve, or Hawā' in Arabic, is not mentioned in Qur'ān, she is rather referred to as "Adam's wife" (Nasr et al.ch. 2). The idea of Eve being created from "one of [Adam's] ribs" (New Revised Standard Version Gen. 2.21) is not mentioned in the Qur' ān. However, in his commentary on the Qur' ān named tafsìr al-Qurān al-' az̄im, ibn-kathīr (c. 1300-1373), the "Muslim theologian and historian" ("Ibn Kathīr"), mentions that Eve was created from Adam's rib. $\mathrm{He}$ attributes this story to the great Muslim scholar ibn- 'abbās (c. 619-687/688), who was "a Companion of the prophet muhammad" and "the first exegete of the 
Qur' ān" (“"Abd Allāh ibn al- 'Abbās"), as well as other companions of the prophet muhammad (ibn-kathīr 141).

\section{References}

Ackerman, Robert. The Myth and Ritual School: J. G. Frazer and the Cambridge Ritualists. Routledge, 2002.

"'Abd Allāh ibn al- 'Abbās." Britannica Academic, Encyclopædia Britannica, 20 Jul. 1998. 08107888t-1106-y-https-academic-ebcom.mplbci.ekb.eg/levels/collegiate/article/\%CA\%BFAbdAll\%C4\%81h-ibn-al-\%CA\%BFAbb\%C4\%81s/3271. Accessed 25 Sep. 2020 .

'Alī, 'Abdulallah Yūsuf. The Meaning of the Holy Qur'ān. 1989. 11 ${ }^{\text {th }}$ ed., Amana Publications, 2009.

"Apocrypha." Britannica Academic, Encyclopædia Britannica, 7 Nov. 2007. 08107795s-1106-y-https-academic-ebcom.mplbci.ekb.eg/levels/collegiate/article/apocrypha/8013. Accessed 7 Sep. 2020.

as-sawāḥ firās. asāțîr 'al-'awalīn: al-qaș̣ al-qur'āniyy wa mutawāziyātu attauratīyyh. 2013. $2^{\text {nd }}$ ed., at-takawīn Publishing House, 2016.

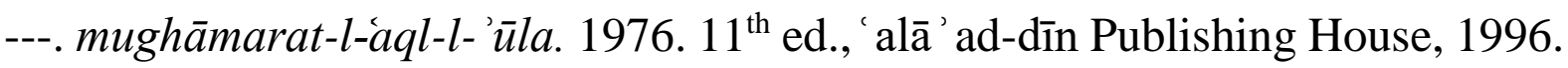

Barnes, Albert. "Genesis 11." Barnes Notes on the Old and New Testaments, Baker Books, $1983 . \quad B i b l e \quad H u b$, biblehub.com/commentaries/barnes/genesis/11.htm.S Accessed 16 May. 2020 .

Bascom, William. "The Form of Folklore: Prose Narrative." Sacred Narrative: Readings in the Theory of Myth, edited by Alan Dundes, U of California P, 1984, pp. 5-29.

"Biblical literature." Britannica Academic, Encyclopædia Britannica, 
20Aug.2020. 081075u5e-1104-y-https-academic-eb-

com.mplbci.ekb.eg/levels/collegiate/article/biblical-literature/110574.

Accessed 30 Aug. 2020.

Bottici, Chiara. A Philosophy of Political Myth. Cambridge UP, 2007.

"Chaldea." Britannica Academic, Encyclopædia Britannica, 20 Jul. 1998. 08107735m-1103-y-https-academic-ebcom.mplbci.ekb.eg/levels/collegiate/article/Chaldea/22273. Accessed 4 Nov. 2020.

Chidester, David. "Credo Mutwa, Zulu Shaman: The Invention and Appropriation of Indigenous Authenticity in African Folk Religion." Journal for the Study of Religion, vol. 15, no. 2, 2002, pp. 6585. JSTOR, www.jstor.org/stable/24764371. Accessed 26 Sept. 2020.

"Creation myth." Britannica Academic, Encyclopædia Britannica, 2 Nov. 2016. 08107y2ib-1103-y-https-academic-ebcom.mplbci.ekb.eg/levels/collegiate/article/creation-myth/109402. Accessed 22 Jul. 2020.

Dalley, Stephanie, translator. Myths from Mesopotamia: Creation, the Flood, Gilgamesh, and Others. Edited by Stephanie Dalley, reissued ed., Oxford UP, 2008.

Franz, Marie-Louis von. Creation Myths, 1972. Kobo Rev. ed., Shambhala Publications, Inc., 1995.

Gray, Andrew. "The two paradises." Biblical Illustrator, edited by Joseph S. Exell, vol. 1, Delmarva Publications, Inc., 2015. Bible Hub, biblehub.com/commentaries/illustrator/genesis/2.htm. Accessed 11 May. 2020 .

Habermas, Jürgen, and Seyla Ben-Habib. "Modernity-An Incomplete Project." The Anti-Aesthetic: Essays on Postmodern Culture, edited by Hal Foster, Bay Press, 1983, pp. 3-15.

"Hebrew Bible." Britannica Academic, Encyclopædia Britannica, 20 May. 2020. 081075tw9-1104-y-https-academic-eb- 
com.mplbci.ekb.eg/levels/collegiate/article/Hebrew-Bible/56983. Accessed 30 Aug. 2020.

Heidel, Alexander. The Babylonian Genesis: The Story of the Creation. The University of Chicago P, 1951

"Hyle." Merriam-Webster.com

Dictionary, Merriam-Webster, https://www.merriam-webster.com/dictionary/hyle. Accessed 4 Nov. 2020.

"Ibn Kathīr." Britannica Academic, Encyclopædia Britannica, $20 \quad$ Jul. 2016. 08107888t-1106-y-https-academic-ebcom.mplbci.ekb.eg/levels/collegiate/article/Ibn-Kath\%C4\%ABr/41922. Accessed 25 Sep. 2020.

ibn-kathīr, 'bū-l-fidā'. tafsīr al-Qurān al-'azīm. Edited by Muḥammad Shams addīn, vol. 1, dār al-kutub al- 'ilmiyyah, 1998.

"Indaba." Merriam-Webster.com

Dictionary,

Merriam-Webster, https://www.merriam-webster.com/dictionary/indaba. Accessed 21 Jun. 2020.

"James Randolph Vigne." South African History Online, South African History Online (SAHO), 2019, www.sahistory.org.za/people/james-randolphvigne. Accessed 26 Sept. 2020.

"King James Version (KJV)." Britannica Academic, Encyclopædia Britannica, 18 May. 2020. 0810779yb-1106-y-https-academic-ebcom.mplbci.ekb.eg/levels/collegiate/article/King-James-Version/45516. Accessed 8 Sep. 2020.

Mavhunga, Clapperton, and Wolfram Dressler. "On the Local Community: The Language of Disengagement?" Conservation and Society, vol. 5, no. 1, 2007, pp. 44-59. JSTOR, www.jstor.org/stable/26392871. Accessed 21 June 2020.

Mutwa, Credo. Indaba, My Children, 1964. Canongate, 1998.

Mutwa, Credo, and Credo Mutwa. "Prologue." Indaba, My Children, 1964. Canongate, 1998, pp. xv-xvi. 
"Mythology and Literature." Cassell Encyclopaedia of Literature, Edited by S. H. Steinberg et al., vol. 1, 1953.

Nasr, Seyyed Hossein, et al., editors. The Study Quran: A New Translation and Commentary. HarperOne, an Imprint of HarperCollins Publishers, 2015.

New Revised Standard Version. The National Council of Churches, 1989, Bible Study Tools, www.biblestudytools.com/nrs/genesis/1.html.

"Philosophe." Britannica Academic, Encyclopædia Britannica, 5 Aug.2019. 08107rox7.1103.y.https.academic.eb.com.mplbci.ekb.eg/level s/collegiate/article/philosophe/59726. Accessed 20 Aug. 2019.

Smith, George. The Chaldean Account of Genesis: Containing the Description of the Creation, the Deluge, the Tower of Babel, the Destruction of Sodom, the Times of Patriarchs, and Nimrod; Babylonian Fables, and Legends of the Gods ; from the Cuneiform Inscriptions. London, Sampson Low, Marston, Searle, and Rivington, 1880.

"Tafsīr." Britannica Academic, Encyclopædia Britannica, 27 Sep. 2019. 08107888t-1106-y-https-academic-eb-

com.mplbci.ekb.eg/levels/collegiate/article/tafs\%C4\%ABr/70900.

Accessed 25 Sep. 2020.

"Torah." Britannica Academic, Encyclopædia Britannica, 18 Sep. 2019. 081075tw9-1104-y-https-academic-eb-

com.mplbci.ekb.eg/levels/collegiate/article/Torah/72921. Accessed 30 Aug. 2020.

Weber, Max. "Science as a Vocation." The Vocation Lectures: Science as a Vocation, edited by David Owen and Tracy B. Strong, translated by Rodney Livingstone, by Max Weber, Hackett, 2004, pp. 1-31.

"Yggdrasill." Britannica Academic, Encyclopædia Britannica, 8 Apr. 2011. 08107v0vk-1105-y-https-academic-ebcom.mplbci.ekb.eg/levels/collegiate/article/Yggdrasill/77958. Accessed 16 May. 2020.

"Zulu." Britannica Academic, Encyclopædia Britannica, 9 Feb. 2007. 0810788tz1106-y-https-academic-ebDOI: $10.21608 / \mathrm{MISJ} .2020 .44130 .1006$ 
com.mplbci.ekb.eg/levels/collegiate/article/Zulu/78488\#. Accessed 26 Sep. 2020. 


\section{أسطرة قصة الخلق فى إندابا، يا أبنائى}

مستخلص

تهدف هذه الورقة البحتية إلى در اسـة قصـة خلق الكون فى الكتاب الأول من النص الأفريقى لقبيلة البانتو:

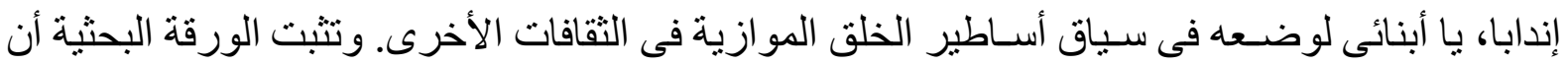
النص قيد الدر اســة هو أسـطورة خلق مقدسـة تخبرنا عن نشـأة الكون. ولتحقيق هذه الغاية، يقارن الباحث

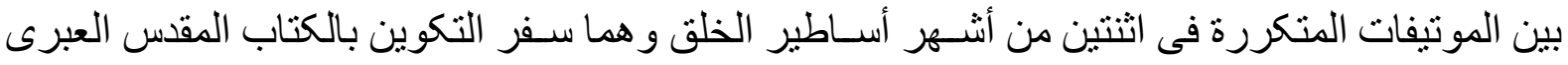

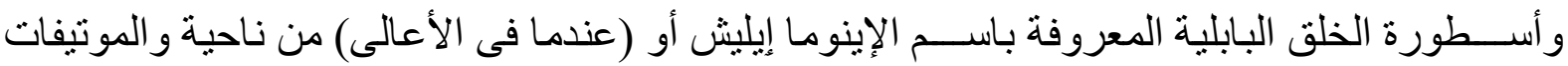

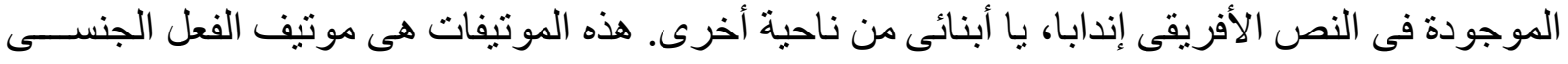
كوسيلة للخلق، وموتيف الثـل البشرى للخالق الأول وموتيف إحلال النظام بعد الفوضى الافى وموتيف الخلق

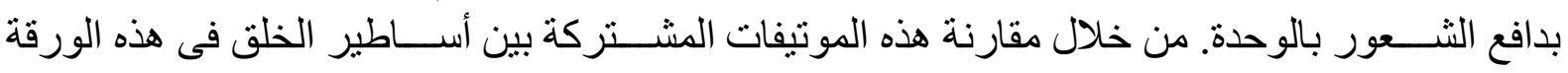

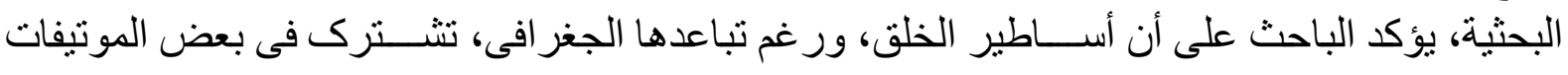

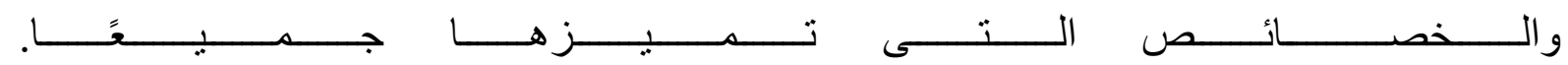

الكلمات المفتاحية: بانتو ، أسطورة الخلق، سفر التكوين، الإينوما إيليش، إندابا 